\title{
Commentary: Fish or cut bait: The importance of defining the safety and efficacy of thoracic transplantation using donors with hepatitis $\mathbf{C}$
}

\author{
Christian A. Bermudez, MD, and Maria M. Crespo, $\mathrm{MD}^{\mathrm{b}}$ \\ From the a Division of Cardiovascular Surgery, Department of Surgery, University of Pennsylvania, Perelman \\ School of Medicine, Philadelphia; and ${ }^{\mathrm{b}}$ Division of Pulmonary, Allergy and Critical Care, University of Penn- \\ sylvania Health System, Philadelphia, Pa. \\ Disclosures: Authors have nothing to disclose with regard to commercial support. \\ Received for publication Oct 1, 2019; revisions received Oct 1, 2019; accepted for publication Oct 1, 2019; \\ available ahead of print Jan 8, 2020. \\ Address for reprints: Christian A. Bermudez, MD, 3400 Spruce St, Philadelphia, PA 19104 (E-mail: Christian. \\ bermudez@uphs.upenn.edu). \\ J Thorac Cardiovasc Surg 2020;159:2130-1 \\ $0022-5223 / \$ 36.00$ \\ Copyright (c) 2020 Published by Elsevier Inc. on behalf of The American Association for Thoracic Surgery \\ https://doi.org/10.1016/j.jtcvs.2019.10.008
}

The demand for thoracic organ transplantation has continued to increase and despite better use and distribution of organs, mortality while waiting for an organ is high. In $2017,7 \%$ to $8 \%$ of heart and lung transplant candidates died on the waitlist. ${ }^{1,2}$ Although thoracic transplant centers have gained more experience in donor management and are actively expanding the standard donor criteria established in $2003,{ }^{3}$ we continue to search for options to increase organ availability. Recently, access to direct-acting antiviral (DAA) therapies coupled with an increasing number of potential donors infected with hepatitis $\mathrm{C}$ virus $(\mathrm{HCV})$ has led the transplant community to consider the use of organs from $\mathrm{HCV}$-positive donors for recipients without $\mathrm{HCV}$ infection.

Since 2002, there has been a significant increase in acute $\mathrm{HCV}$ infection, closely tied to the opioid epidemic in the United States and primarily affecting persons younger than the age of 30 years. ${ }^{4}$ The global prevalence of hepatitis $\mathrm{C}$ has been estimated as antibody sero-positivity in 110 million people and $\mathrm{HCV}$ viremia in 80 million people. ${ }^{5}$ Deaths related to intravenous drug use or opioid overdose now account for $20 \%$ to $30 \%$ of potential donors and for $65 \%$ of donors in the United States who test positive for to consider that donors with $\mathrm{HCV}$ may become a significant source of organs suitable for transplant if hepatitis $C$ can be effectively treated.

In this issue of the Journal, Van Raemdonck and colleagues $^{7}$ present an invited expert opinion detailing some of the most recent experiences using organs from $\mathrm{HCV}$ infected donors in patients awaiting thoracic transplantation and share some of the potential challenges of this strategy. As presented by the authors, the results seen in heart and lung transplantation demonstrate no difference in the early survival of patients who received organs from $\mathrm{HCV}$-positive $\mathrm{HCV}$ by nucleic acid amplification testing. ${ }^{6}$ It is reasonable

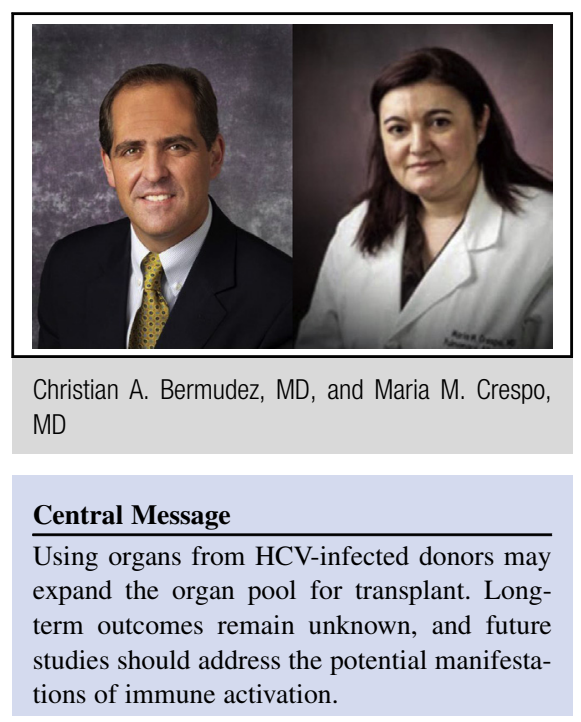

See Article page 2121. donors as compared with patients who received organs from $\mathrm{HCV}$-negative donors, with a rate of seroconversion between $67 \%$ and $95 \%$. The potential challenges of using $\mathrm{HCV}$-positive donors include possible interactions of DAAs with other drugs administered early after transplant, an unknown impact of preemptive versus delayed treatment, and the efficiency of short-duration versus fullcourse DAA therapy. As Van Raemdonck and colleagues note, there are potentially negative effects of immune activation from de novo viral infection that may lead to unintended consequences such as organ rejection, other infections, and metabolic complications. These were previously encountered in lung and heart transplant recipients who received organs from human immunodeficiency virus-positive donors.

Although preliminary results are encouraging, several issues merit further exploration and research. We have a limited understanding of the virologic factors that may play a role in the successful thoracic transplantation of organs from $\mathrm{HCV}$-positive donors to $\mathrm{HCV}$-negative recipients. Preliminary data suggest that late relapses of HCV may occur after lung transplantation. ${ }^{8}$ Although these reactivations may be easily controlled, it will be important to evaluate the impact on allograft and patient outcomes. 
The incidence of primary graft dysfunction, acute and chronic rejection, and transplant vasculopathy must be determined. The immunology of donor-derived HCV may be an important predictor of short- and long-term outcomes. In addition, other manifestations of immune activation, specifically the risk of coinfections with other infectious pathogens, may lead to comorbidities. As the use of HCVinfected donors expands, consideration may be given to including donors with coinfection of other hepatitis viruses, such as hepatitis B virus, and safety must be examined. Patient education and counseling is recommended to promote medication adherence, recognition of adverse events, and prevention of HCV transmission.

Another important issue, which is not addressed in this article, is the financial implications of using $\mathrm{HCV}$-positive donors. The enthusiasm for DAA therapies has often been tampered by challenges to drug access, largely due to cost barriers to payer approval, which delay therapy initiation. ${ }^{9}$ Despite these challenges, recent evidence suggests that the use of HCV-positive organs can reduce waitlist time, improve waitlist survival, and potentially could lead to a significant reduction in health care costs. ${ }^{10}$ Finally, it is important to emphasize to urgency of deriving a universal consensus on the management, education, and follow-up of patients awaiting thoracic organ transplant who may receive an organ from an $\mathrm{HCV}$-positive donor.

\section{References}

1. Valapour M, Lehr CJ, Skeans MA, Smith JM, Uccellini K, Lehman R, et al. OPTN/SRTR 2017 annual data report: lung. Am J Transplant. 2019;19(suppl 2):404-84.

2. Colvin M, Smith JM, Hadley N, Skeans MA, Uccellini K, Lehman R, et al. OPTN/SRTR 2017 annual data report: heart. Am J Transplant. 2019;19(suppl 2):323-404.

3. Orens JB, Boehler A, de Perrot M, Estenne M, Glanville AR, Keshavjee S, et al. A review of lung transplant donor acceptability criteria. J Heart Lung Transplant. 2003;22:1183-200.

4. Zibbell JE, Asher AK, Patel RC, Kupronis B, Iqbal K, Ward JW, et al. Increases in acute hepatitis $\mathrm{C}$ virus infection related to a growing opioid epidemic and associated injection drug use, United States, 2004 to 2014. Am J Public Health. 2018 108:175-81.

5. Gower E, Estes C, Blach S, Razavi-Shearer K, Razavi H. Global epidemiology and genotype distribution of the hepatitis C virus infection. J Hepatol. 2014; 61:S45-57.

6. Moayedi Y, Fan CPS, Gulamhusein AF, Manlhiot C, Ross HJ, Teuteberg JJ, et al. Current use of hearts from hepatitis C viremic donors. Circ Heart Fail. 2018;11: e005276.

7. Van Raemdonck D, Nevens F, Van Cleemput J, Vos R, Arne Neyrinck A, Verleden GM. Fishing in the thoracic organ donor pool: what next if the catch of the day got infected with hepatitis C virus? J Thorac Cardiovasc Surg. 2020;159:2121-5.

8. Cypel M, Feld J, Singer LG, Marks N, Bahinskaya I, Kuczynski M, et al. Transplantation of NAT $+\mathrm{HCV}$ donor lungs into non-infected recipients followed by treatment with sofosbuvir/velpatasvir (S/V). J Heart Lung Transplant. 2019; 38(suppl):S65.

9. Marks K, Naggie S. Management of hepatitis C in 2019. JAMA. 2019;322: 355-6.

10. Gernhofer YK, Brambatti M, Greenberg BH, Adler E, Aslam S, Pretorius V. The impact of utilizing hepatitis $\mathrm{C}$ virus nucleic acid test-positive donor hearts on heart transplant waitlist time and transplant rate. J Heart Lung Transplant. 2019;38:1178-88. 